\title{
Rat Milk Maintains Intestinal Lactase Activity in Rat Pups whereas Artificial Formulas Do Not
}

\author{
KWO-YIH YEH AND PETER R. HOLT \\ Division of Gastroenterology, St. Luke's-Roosevelt Hospital Center, and Department of Medicine, College of \\ Physicians and Surgeons of Columbia University, New York, New York 10025
}

\begin{abstract}
Intestinal lactase activity is maintained at high levels in suckling rats during the first $2 \mathrm{wk}$ after birth. When 12-day-old rat pups were either mother fed (MF) or artificially reared (AR) with natural rat milk or several artificial formulas, the small intestines had gained similar weight in all animal groups by 16 days except in AR rats fed a chemically defined formula. In the ileum, villus length was similar in MF and $A R$ rats, but crypt depth was significantly higher in all groups of AR rats. Ileal absorptive cells in both $M F$ and $A R$ rats showed immature characteristics, including supranuclear vacuoles, apical tubular systems, and pinocytotic vesicles. Jejunal lactase specific activity and total intestinal lactase activity were significantly higher in AR rats fed rat milk than MF rats at 16 days. Ileal lactase specific activity was similar in these two animal groups. In contrast, AR rats fed artificial formulas supplemented with either glucose or lactose as the sole carbohydrate source exhibited significantly lower ileal lactase specific activity and total intestinal lactase activity than MF rats. Intestinal sucrase activity was prematurely elevated in all $A R$ rats, even when fed natural rat milk. Addition of prolactin $(3.3 \mu \mathrm{g} / \mathrm{ml})$ to an artificial formula did not prevent the premature decrease in intestinal lactase specific and total activities in $A R$ rats. We conclude that ( 1 ) natural rat milk plays a cardinal role in maintaining lactase activity during the suckling period; (2) the lactose and prolactin content of rat milk are not essential components in maintaining lactase activity in $A R$ rat pups; and (3) the artificial feeding procedure, rather than dietary composition, induces premature elevation of sucrase activity. (Pediatr Res 19: 963-967, 1985)
\end{abstract}

\section{Abbreviations}

MF, mother fed

$\Lambda R$, artificially reared

CMF, cow milk formula

RCF, Rose carbohydrate-free formula

CDF, chemically defined formula

$\mathrm{G}$, glucose

L., lactose

Intestinal lactase, which is essential for the hydrolysis and absorption of lactose, is abundant in mammals at birth, remains at high activity before weaning and then generally falls to a low level (1). In the rat, lactase activity is high for about $2 \mathrm{wk}$ after

Received February 19. 1985: accepted April 30.1985.

Reprint requests to Dr. Kwo-yih Yeh. Gastroenterology Division, S and R 12, St. Luke's-Roosevelt Hospital Center. 114th Street at $\wedge$ msterdam Avenue. New York. NY 10025

Supported by NIH Research Grant AM-33916. birth and declines gradually thereafter to reach adult levels during the 4th wk (2-4). In parallel, intestinal maltase activity, which is low, and sucrase activity, which is absent during the first 2 postnatal wk, increase rapidly in the end of the 3rd wk (4). Accumulated evidence indicates that the ontogenetic increase of maltase and sucrase in the rat is modulated by hormones produced by the pituitary-adrenal and pituitary-thyroid systems (5-7 ), and the ontogenetic decrease of intestinal lactase activity is regulated in part by the pituitary-thyroid system (8).

Previous studies from our laboratory have shown that lactase activity at 24 days postpartum is higher in rats hypophysectomized at 6 days than at 10 days of age (8), suggesting that pituitary hormones have exerted their effect on intestinal lactase activity as early as 6 days of age. Consistent with this suggestion is a report that serum concentrations of free thyroxine and triiodothyronine rise rapidly after 5 days of age (9). Intestinal lactase activity does not decline until the end of the 2 nd postpartum wk $(2-4,8)$, so that other factors must antagonize the effect of the pituitary-thyroid system to maintain lactase activity during this period. Since prolonged nursing delays the normal decline in intestinal lactase activity $(10,11)$, factors in maternal milk might be responsible for maintaining lactase activity. This hypothesis is supported indirectly by our recent findings that lactase activity is precociously decreased in the ileum of artificially reared rat pups fed formula diets $(12,13)$.

To establish whether maternal rat milk maintains intestinal lactase activity in rat pups, we have compared the effect of natural rat milk and isocaloric formulas on intestinal lactase activity in AR rats. Since lactose protects lactase activity in vitro (10), and since rat milk contains high concentrations of prolactin (14) which antagonizes the effects of thyroxine on the regulation of amphibian metabolism $(15,16)$, studies were performed to determine whether dietary lactose or prolactin maintains intestinal lactase activity in AR rats.

\section{MATERIALS AND METHODS}

Artificial feedings. Sprague-Dawley rats, mated and bred in our animal room, had intragastric cannulae implanted at 12 days of age (17). Rats were housed individually in plastic cups containing hardwood laboratory bedding and floated in a $35^{\circ} \mathrm{C}$ water bath. Diets were infused continuously at rates which were increased gradually from $4.5 \mathrm{ml}$ at $12-13$ days to $8.0 \mathrm{ml}$ at $15-$ 16 days of age. In the first experiment, AR rats were fed either rat milk collected from dams 12-16 days postpartum, or an isocaloric carbohydrate-free soy protein formula base (RCF, Ross Laboratories, Columbus, $\mathrm{OH})$ supplemented with casein hydrolysate, corn oil and either lactose (RCFL) or glucose (RCFG) to give the same caloric composition of protein, fat, and carbohy-drate found in rat milk (18); a cow milk formula (CMF) $(12,19$, 20 ); or a $14 \%$ solution of chemically defined fat-free formula (21) supplemented with either lactose (CDFL) or glucose CDFG) at the same caloric density of carbohydrate and protein as CMF. 
In rats fed the defined fat-free diets, corn oil containing $2 \mathrm{mg}$ of $d l-\alpha$-tocopherol, $4 \mathrm{mg} d l-\alpha$-tocopheryl acetate, and vitamins A $(0.33 \mathrm{mg}), \mathrm{D}(0.35 \mathrm{mg})$ and $\mathrm{K}(0.55 \mathrm{mg})$ was infused separately daily (21). Some rat pups were suckled (MF) and served as controls. In the second experiment, $A R$ rats were divided into two groups receiving either RCFL or RCFL supplemented with sheep prolactin $(3.3 \mu \mathrm{g} / \mathrm{ml}$, Sigma Chemical Company, St. Louis, $\mathrm{MO}$ ). A group of MF rats served as control.

Disaccharidase assays. Animals were sacrificed at 16 days between 0900 and $1100 \mathrm{~h}$. The small intestine from the ligament of Treitz to the ileocecal junction was removed, washed, blotted dry, divided into halves of equal length and weighed. The proximal half was designed as jejunum and the distal half as ileum. The intestine was homogenized in $0.15 \mathrm{M} \mathrm{NaCl}$ with a Vir Tis homogenizer (Am Sci Product, Edison, NJ). Lactase, sucrase and maltase activities were assayed by methods described previously (6-8) and protein by the Lowry technique (22). Specific activities were expressed as $\mu \mathrm{mol}$ substrate hydrolyzed per $\mathrm{mg}$ protein per $\mathrm{h}$ and total activity was expressed as $\mu \mathrm{mol}$ substrate hydrolyzed per jejunum plus ileum per h.

Histology. Morphologic observations were made in ileum since we previously showed that the premature decrease of lactase activity occurred first in the distal intestine (12). Only animals fed the diets containing lactose were studied since intestinal weight and disaccharidase activities were similar in AR rats fed lactose or glucose. For light microscopy, a segment of ileum about $3 \mathrm{~cm}$ from the ileocecal junction was removed, cut open, flattened on a paraffin sheet, fixed in Carnoy's fixative, and embedded in paraffin. Longitudinal sections at $5 \mu \mathrm{m}$ thickness were stained with hematoxylin and eosin. Villus length and crypt depth were measured from 10 well-oriented villi and crypts. For electron microscopy, small segments of ileum from MF and AR rats fed either rat milk or CMF were fixed in $4 \%$ glutaraldehyde in $0.1 \mathrm{M}$ phosphate buffer, at $\mathrm{pH} 7.3$, overnight, postfixed in $1 \%$ $\mathrm{OsO}_{4}$ for $2 \mathrm{~h}$, and embedded in Epon. Tissues were cut at $800 \AA$ thickness with a Porter-Blum MT-2 ultramicrotome. Sections were stained in uranyl acetate, followed by lead citrate, and observed in a Hitachi HU-12A electron microscope.

Statistical analysis. Unless otherwise indicated the results were evaluated by analysis of variance. When the $F$ value obtained from analysis of variance was significantly different, Duncan's multiple range test (23) was then applied to test differences among groups.

\section{RESULTS}

Body and intestinal growth. AR rats infused with rat milk weighed substantially less at 16 days than MF rats (Table 1) even though the caloric intake of AR rats was calculated to approximate that of MF rats (24). Slow body weight gain also was observed in AR rats fed RCFL, RCFG, and CMF. Reduced

Table 1. Body and small intestinal wt in $M F$ and in AR rats $(\text { mean } \pm S E M)^{*}$

\begin{tabular}{|c|c|c|c|c|}
\hline Group & $\begin{array}{c}\text { Age } \\
\text { (days) }\end{array}$ & $\begin{array}{c}\text { No. of } \\
\text { Rats }\end{array}$ & Body $(\mathrm{g})$ & $\begin{array}{c}\text { Small } \\
\text { intestine } \\
(\mathrm{mg})\end{array}$ \\
\hline \multirow[t]{2}{*}{ MF rats } & 12 & 7 & $23.9 \pm 1.1 \dagger$ & $774 \pm 19 \ddagger$ \\
\hline & 16 & 6 & $33.5 \pm 1.8$ & $1076 \pm 114$ \\
\hline AR rats + RM & 16 & 5 & $27.4 \pm 1.0 \%$ & $971 \pm 42$ \\
\hline$+\mathrm{RCFL}$ & 16 & 5 & $27.0 \pm 0.6 \%$ & $1057 \pm 38$ \\
\hline$+\mathrm{RCFG}$ & 16 & 5 & $28.4 \pm 0.9+$ & $1042 \pm 49$ \\
\hline$+C M F$ & 16 & 6 & $27.0 \pm 0.5 t$ & $1049 \pm 32$ \\
\hline$+\mathrm{CDFL}$ & 16 & 5 & $24.8 \pm 1.2 \dagger$ & $837 \pm 26 t$ \\
\hline$+\mathrm{CDFG}$ & 16 & 5 & $24.6 \pm 0.7 \dagger$ & $817 \pm 49$ \\
\hline
\end{tabular}

* Rat pups at 12 days of age were MF or AR with either rat milk (RM), RCFL, or RCFG, a CMF, or a chemically defined formula supplemented with lactose (CDFL) or glucose (CDFG).

$\dagger_{p}<0.01$ and $f_{p}<0.05$ compared with MF rats at 16 days.
Table 2. Villus length and crypt depth in the ileum of $M F$ and $A R$ rats on differing diets (mean $\pm S E$ )

\begin{tabular}{cccc}
\hline Groups & $\begin{array}{c}\text { No. of } \\
\text { rats }\end{array}$ & $\begin{array}{c}\text { Villus length } \\
(\mu \mathrm{m})\end{array}$ & $\begin{array}{c}\text { Crypt depth } \\
(\mu \mathrm{m})\end{array}$ \\
\hline MF rats & 5 & $282 \pm 7$ & $42 \pm 1.9 \dagger$ \\
AR rats + RM & 3 & $283 \pm 9$ & $65 \pm 7.6$ \\
+ RCFL & 5 & $269 \pm 12$ & $70 \pm 3.7$ \\
+ CML & 4 & $310 \pm 23$ & $72 \pm 4.3$ \\
+ CDFL & 4 & $262 \pm 9$ & $63 \pm 4.2$ \\
\hline
\end{tabular}

* Rat pups were MF or AR with rat milk (RM) or artificial formulas from 12 days of age and were sacrificed at 16 days.

$\dagger p<0.01$ versus other values in the same column.

weight gain was not due to changes in the gastric emptying rate since the weight of gastric contents were similar in all AR groups (114-210 mg). However, at the same time the small intestine weight gain in AR rats fed either RM, RCFL, or CMF was comparable to that of MF rats (Table 1). The perfusion rate in AR rats was chosen to maintain similar intestinal weights since the objective of the present studies was to compare intestinal enzyme contents. If sufficient calories are provided to AR rats to maintain normal body weight gain, intestinal hyperplasia occurs $(12,13)$. Intestinal weight did not increase only in AR rats fed CDFL or CDFG. Addition of prolactin into RCFL had no promoting effect on small intestinal or body weight gain (data not shown).

Ileal morphology. At 16 days villus length in MF and AR rats fed either rat milk or artificial formulas containing lactose was similar, but crypt depth in MF rats was significantly lower than that in AR rats (Table 2). No significant difference in crypt depth was found among groups of $A R$ rats.

Ileal morphology was similar in MF and AR rats. Figures 1 to 3 show that epithelial cells covering the upper three-quarters of villi were highly vacuolated in MF rats, in milk fed AR and in CMF fed AR rats. Similar morphology was also found in other AR rats fed RCFL and CDFL diets (data not shown). Ultrastructural studies indicated that the absorptive cell at the middle villus level exhibited one large supranuclear vacuole and associated small vacuoles and apical tubular systems in MF rats (not shown) and AR rats fed rat milk or CMFL (Figs. 4 and 5). The presence of pinocytotic vesicles in absorptive cells implies that these cells are actively taking up luminal nutrients.

Intestinal disaccharidase activities. Lactase specific activity in MF decreased by $28 \%$ in the jejunum but did not change in the ileum (Fig. $6 a$ and $b$, open columns $A$ and $B$ ). Jejunal lactase activity at 16 days of age in $A R$ rats fed rat milk remained at the 12-day-old level (columns $A$ and $C$ ), and was higher than that of 16-day-old $M F$ rats. In $A R$ rats fed diets other than rat milk, jejunal lactase specific activity decreased to the levels found in $\mathrm{MF}$ at 16 days. In contrast to the findings in the jejunum, ileal lactase activity dropped prematurely in rat pups given diets other than rat milk (Fig. $6 b$, columns $D, E, F, G$, and $H$ ).

Although lactase specific activity of jejunum fell, total lactase activity in MF (Fig. 6C, open columns $A$ and $B$ ) increased significantly between 12 and 16 days because intestinal weight rose by $39 \%$. Total lactase activity in AR rats fed rat milk at 16 days was also higher than in MF rats of the same age (columns $B$ and $\left({ }^{\prime}\right.$ ). However, increased lactase activity occured only in rats provided with rat milk and enzyme activity actually decreased in AR rats fed other diets $(p<0.05)$.

In studies on sucrase and maltase activity of $A R$ rats performed in parallel, both specific and total activities of these enzymes were prematurely elevated in the jejunum and ileum (Fig. 6, cross-hatched columns show sucrase activity, maltase activity was similar and is not shown). In MF rats no sucrase activity could be detected at 12 days, and only two of six rats showed low levels of activity at 16 days (Fig. 7 , column $B$ ).

When AR rats were fed RCFL plus prolactin, both specific 
and total intestinal lactase activities declined to levels significantly lower than those of MF rats (Table 3, $p<0.01$ ). Specific lactase activity in both jejunum and ileum and total lactase activity in AR rats fed RCFL plus prolactin were not significantly higher than those in AR rats fed RCFL only $(p>0.05)$.
DISCUSSION

Since body weights of AR rats did not increase as much as MF rats, it was conceivable that malnutrition, possibly resulting from inadequate absorption of nutrients, was responsible for our ob-
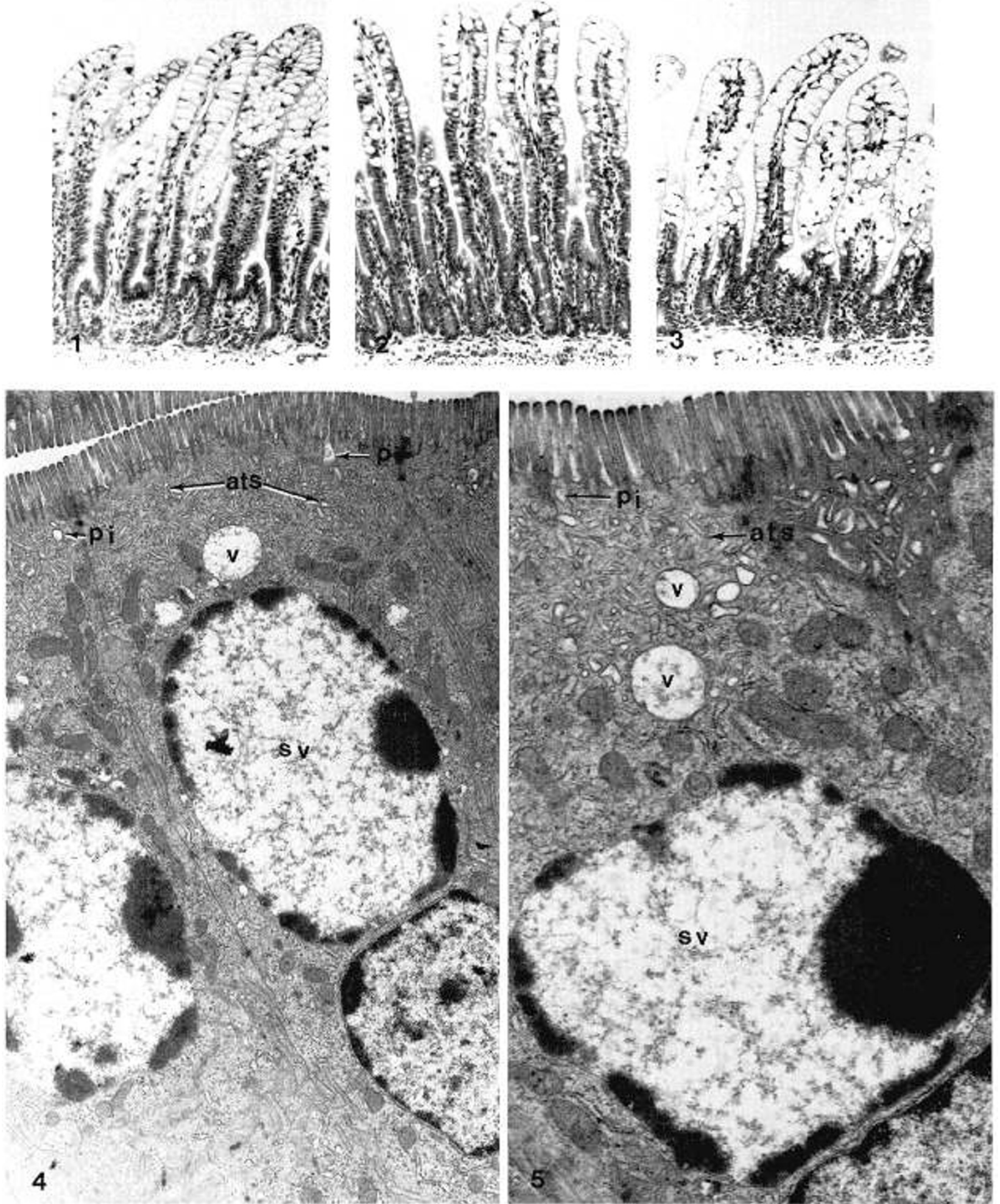

Figs. 1-3. Light microscopy of ileal villi in MF rats ( $I$ ) and in AR rats fed either rat milk (2) or CMFL (3). Vacuolated cells cover the upper three quarters of villi in all animal groups. $\times 110$.

Figs. 4 and 5. Electron micrographs of ileal absorptive cells in AR rats fed rat milk $(4,000 \times 5,000)$ or CMFL $(5,000 \times 10,000)$. Absorptive cells show immature characteristics including pinocytotic invaginations and vesicles $(p)$, apical tubular systems (ats). numerous small vacuoles $(v)$, and a large supranuclear vacuole ( $(\mathrm{s})$. 


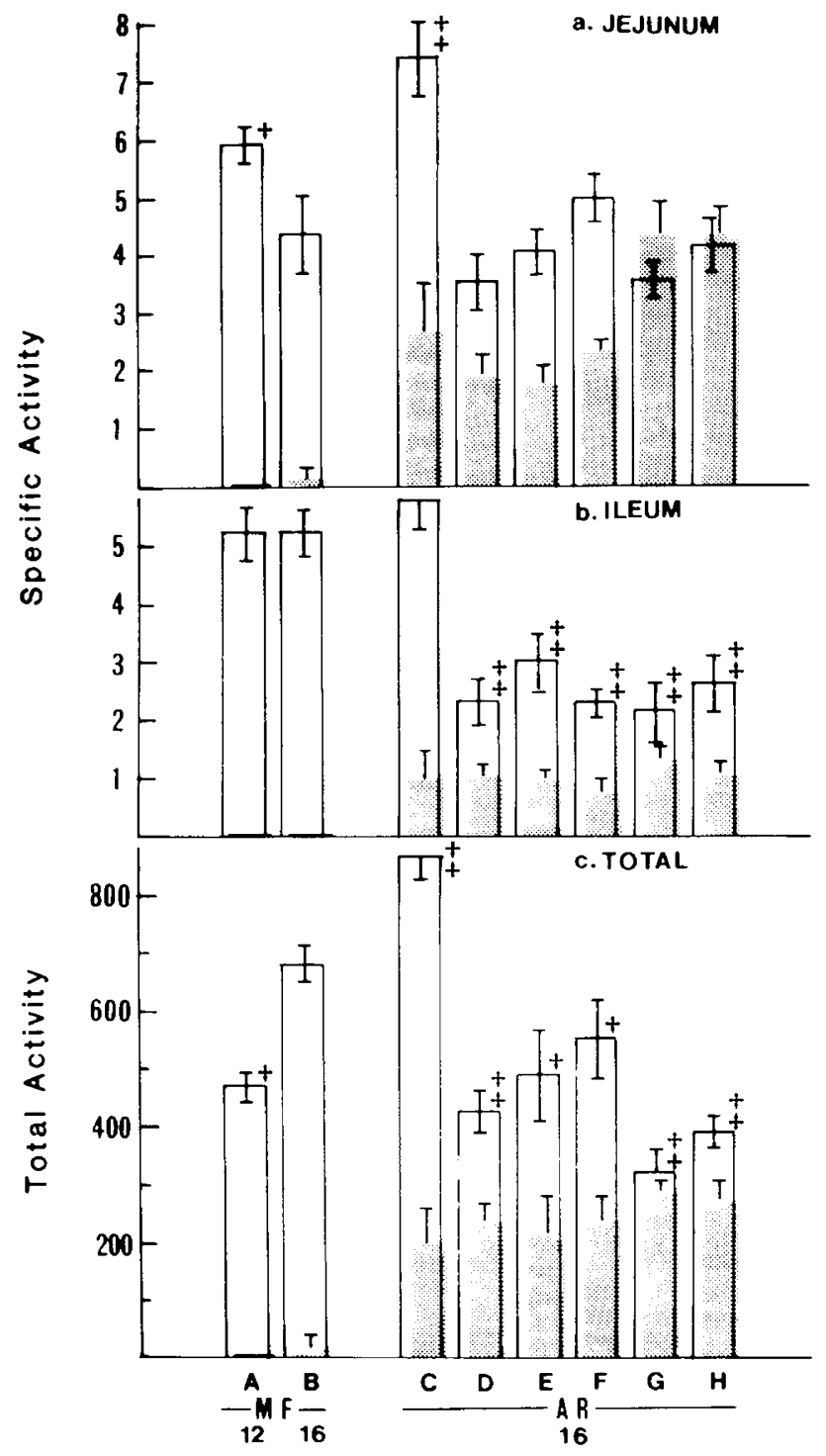

Fig. 6. Specific activities of lactase (open columns) and sucrase (crosshatched (ollumms) in the jejunum $(a)$ and ileum $(b)$ and total intestinal lactase and sucrase activities (c). Rat pups at 12 days of age were MF or $\triangle \mathrm{R}$ with cither rat milk (column (c). RCFL (column D). RCFG (column li). CMF (column $\mathrm{F})$, CDFL (column $(j)$ ) or CDFG (column $I I)$ from 121016 days. Each collumn represents the mean of five to seven animals. I mical lines indicate SEM. For the probability of lactase activity, $t p<$ 0.05 and $t p<0.01$ compare with MF rats at 16 days (column $B$ ).

servation. However, our present studies demonstrated that epithelial cells in AR rats retained high pinocytotic activity. Furthermore, ileal villi of $A R$ rats were not shorter than those of $\mathrm{MF}$ rats. These morphologic characteristics suggest normal intestinal digestive functions in AR rat pups. It is likely that undernutrition of $A R$ rats is the result of a low caloric intake since higher caloric intake is able to support AR rats to gain weight comparable to MF rats $(12,13)$.

Malnutrition and starvation have been shown to elevate intestinal lactase specific activity, but have no effect on total activity $(25,26)$. In the present studies both lactase specific and total activities were increased in AR rats fed rat milk implying that the changes observed cannot be attributed to malnutrition only. Similarly, caloric undernutrition could not have caused the precocious decline in ileal lactase specific activity, since this occurs in AR rats provided with an even higher caloric intake of CMF and RCFL (13).
Lower rates of body weight gain may reflect the effects of stress. Our previous results suggested that changes in intestinal sucrase activity were not induced by the diet $(12,13)$, but appeared to be an effect of stress $(25,27,28)$. This interpretation is supported by recent data in our laboratory showing that serum corticosterone concentrations $24 \mathrm{~h}$ after cannula implantation were $5.30 \pm 0.67 \mu \mathrm{g} / \mathrm{dl}$ in $\mathrm{AR}$ rats fed RCFL diet and $0.47 \pm 0.21$ $\mu \mathrm{g} / \mathrm{dl}$ in MF rats. In contrast to suckling rats, dietary sucrose enhances intestinal sucrase synthesis in adult rats (29). All AR rats in the present studies showed a precocious increase in sucrase (and maltase) independent of the substrate fed. However, stress was not responsible for the decreases in ileal lactase activity since this was maintained by rat milk in AR rats.

The maintenance of high lactase activity in AR rats fed rat milk is consistent with observations that prolonged nursing delays the usual decrease of lactase activity (10). As a result of higher jejunal lactase activity, total lactase activity was significantly higher in AR rats fed rat milk than MF rats. Since a small amount of Purina Chow was present in the stomach of MF rats at 16 days, this partial weaning might be responsible for decreased lactase activity. A precocious decrease of ileal and total intestinal lactase activity occured in AR rats fed RCFL, a formula in which the lactose content closely simulates that of rat milk. Ileal lactase activity also decreased in AR rats fed CMF indicating that evaporated cow milk, which contains $50 \%$ higher lactose concentration than rat milk (12), is unable to prevent the fall in lactase activity. Furthermore, ileal and total intestinal lactase activity fell to the same extent if AR rats were fed artificial formulas containing isocaloric amounts of either lactose or glucose. All of these studies demonstrate unequivocally that the presence of lactose in the milk formula does not maintain intestinal lactase activity.

The precise mechanism for the premature decrease in ileal lactase activity in AR rats fed artificial formulas when compared to rats fed rat milk is unknown. Changes in lactase activity have been shown to be closely related to the turnover rate of intestinal epithelial cells (30). If AR rats fed formulas were to have greater epithelial cell turnover rates than rats fed rat milk, cells with high sucrase and low lactase activity, usually found near the intestinal crypt, conceivably might replace those cells with high lactase activity near the villus tip. Studies of cell turnover rates in response to different diets in $\mathrm{AR}$ rats are in progress.

Intestinal lactase activity is more susceptible to protease degradation than sucrase activity (31), so that low ileal lactase activity might have resulted from increased luminal concentrations of proteases. Increased bacterial protease concentrations might possibly be present in AR rats fed artificial formulas since maternal milk contains antibacterial factors that are not present in artificial formulas $(32,33)$.

In addition to antimicrobial factors and nutrients, rat milk contains several hormones, growth factors, and hormone-binding proteins $(33-36)$. It is likely that one or more of these biologically active components in maternal milk has a role in sustaining intestinal lactase activity during the suckling period. Since rat milk contains high titers of prolactin (14) and since prolactin

Table 3. Effect of prolactin on intestinal lactase activity in $A R$ rats (mean $\pm S E)^{*}$

\begin{tabular}{|c|c|c|c|c|}
\hline \multirow[b]{2}{*}{ Group } & \multirow{2}{*}{$\begin{array}{l}\text { No. of } \\
\text { rats }\end{array}$} & \multicolumn{2}{|c|}{$\begin{array}{l}\text { Specific activity }(\mu \mathrm{mol} / \\
\text { mg protein } / \mathrm{h})\end{array}$} & \multirow{2}{*}{$\begin{array}{c}\text { Total } \\
\text { activity } \\
(\mu \mathrm{mol} / \\
\text { intestine } / \mathrm{h})\end{array}$} \\
\hline & & Jejunum & Ileum & \\
\hline $\mathrm{MF}_{\mathrm{r}}$ & 5 & 4.15 & 19 & $587 \pm 64$ \\
\hline$R$ rats $+R$ & 6 & $2.25 \pm$ & $1.89 \pm$ & \\
\hline$+\mathrm{RCFL}+\mathrm{PRL}$ & 7 & $2.87 \pm 0.23 t$ & $2.65 \pm 0.19 \dagger$ & $381 \pm 53 \dagger$ \\
\hline
\end{tabular}

* Rats at 12 days of age were either MF or AR with RCFL or RCFL plus prolactin (PRL) and were sacrificed at 16 days.

$\dagger p<0.01$ versus MF rats. 
antagonizes the effect of thyroxine on amphibian metamorphosis $(15,16)$, it might similarly antagonize the suppresive effect of thyroxine on intestinal lactase activity in suckling rats. The present results however, show that sheep prolactin at a concentration 10 times higher than in rat milk (14), has no effect on sustaining intestinal lactase activity. Further studies of feeding $A R$ rats with a formula supplemented with other components in milk will be needed to define the specific components responsible for maintaining intestinal lactase activity during this important postnatal period.

Acknowledgments. The authors thank Mrs. Deborah G. Gordon for collecting rat milk, Ms. Frances Du for excellent technical help, and Ms. Maura McGloin for secretarial assistance.

\section{REFERENCES}

1. Koldovsky O 1969 Development of the Function of the Small Intestine in Mammals and Man. Karger. White Plains. NY pp 44-59

2. Docll R. Kretchmer N 1962 Studies of small intestine during development. 1. Distribution and activity of $\beta$-galactosidase. Biochem Biophys Acta 62:353362

3. Kretchmer N 1971 Memorial lecture: lactose and lactase-a historical perspective. Gastroenterology 61:805-813

4. Rubino A. Zimbalatti F. Auricchio S 1964 Intestinal disaccharidase activities in adult and suckling rats. Biochem Biophys Acta 92:305-31!

5. Docll R, Kretchmer N 1964 Intestinal invertase: precocious development of activity after injection of Hydrocortisone. Science 143:42-44

6. Ych KY. Moog F 1975 Development of the small intestine in the hypophysectomized rat. I. Growth. histology and activity of alkaline phosphatase maltase and sucrase. Dev Biol 47:156-172

7. Yeh KY. Moog F 1975 Development of the small intestine in the hypophysectomized rat. II. Influence of cortisone, thyroxinc, growth hormone, and prolactin. Dev Biol 47:173-184

8. Yeh KY, Moog F 1974 Intestinal lactase activity in suckling rats:influence of hypophysectomy and thyroidectomy. Science 183:77-79

9. Walker P. Dubois JD. Dussault JH 1980 Free thyroid hormone concentrations during post-natal development in the rat. Pediatr Res 14:247-249

10. Lebenthal E. Sunshine P. Kretchmer N 1973 Effect of prolonged nursing on the activity of intestinal lactase in rats. Gastroenterology 64:1136-1141

11. Lee PC. Lebenthal E 1983 Early weanling and precocious development of small intestine in rats: genetic. dictary or hormonal control. Pediatr Res $17: 645-650$

12. Yeh KY 1983 Small intestine of artificially reared rat pups: weight gain and changes in alkaline phosphatase. lactase and sucrase activities during development. J Nutr 113:1489-1495

13. Yeh KY 1983 Small intestine of artificially reared rat pups: effect of caloric intake and dietary composition on growth and disaccharidase activities. J Nutr 113:1496-1502

14. McMurphy JP. Malven PV 1974 Radioimmunoassay of endogenous and exogenous prolactin in milk of rats. J Endocrinol 61:211-217
15. Derby A. Etkin W 1968 Thyroxine induced tail resorption in vitro as affected by anterior pituitary hormones. J Exp Zool 169:1-8

16. Brown PS, Frye BE 1969 Effects of prolactin and growth hormone on growth and metamorphosis of tadpoles of the frog's Rana pipiens. Gen Comp Endocrinol 13:126-138

17. Hall WG 1975 Weaning and growth of artificially reared rats. Science 190:1313-1315

18. Keen CL. Lonnerdal B. Clegg M. Hurlcy LS 1981 Developmental changes in composition of rat milk: trace elements, minerals, proteins, carbohydrate and fat. J Nutr 111:226-230

19. Messer M, Thoman EB. Therrasa AG. Dollman PR 1969 Artificial feeding of infant rats by continuous gastric infusion. $J$ Nutr 98:404-410

20. Dymsza HA. Czajka DM, Miller SA 1964 Influence of artificial diet on weight gain and body composition of the neonatal rat. J Nutr 84:100-106

21. Reddy BS, Wostman BS. Pleasants JR 1968 Nutritionally adequate diets for germ-free animals. In: Coats ME (ed) Germ Free Animal in Research. Academic press, London, pp 87-111

22. Lowry OH. Rosebrough NJ, Farr AL. Randall RJ 1951 Protein measurement with the folin phenol reagent. J Biol Chem 193:265-275

23. Duncan DB 1955 Multiple Range and Multiple F tests. Biometrics 11:1-42

24. Godbole VY. Grudleger ML, Pasquine TA. Theven SW 1981 Composition of rat milk from day 5 to 20 of lactation and milk intake of lean and preobese Zucker pups. J Nutr 111:480-487

25. Boylc JT, Koldovsky O 1980 Critical role of adrenal glands in precocious increase in jejunal sucrase activity following premature weaning in rats: negligible effect of food intake. J Nutr 110:169-177

26. Hatch TF, Lebenthal E, Branski D, Krasner J 1979 The effect of carly postnatal acquired malnutrition on intestinal growth, disaccharidases and enterokinase. J Nutr 109:1874-1879

27. Lebenthal E. Sunshine P. Kretchmer 1972 Effect of carbohydrate and corticosteroids on activity of $\alpha$-glucosidases in intestine of the infant rat. J Clin Invest 51:1244-1250

28. Yeh KY 1982 Differentiation of small intestinal epithelium in hypophysectomized and artificially reared suckling rats. $\mathbf{J}$ Cell Biol 95:33a(abstr)

29. Cezard JP. Broyant JP. Cuisinier-Gleizes P. Mathieu H 1983 Sucrase-isomaltase regulation by dietary sucrase in the rat. Gastroenterology 84:18-25

30. Tsuboi KK, Kwong LK. Neu J, Sunshine P 1982 A proposed mechanism of normal intestinal lactase decline in the postweancd mammal. Biochem Biophys Res Commun 101:645-652

31. Seetharam B, Perrillo R. Alpers DH 1980 Effect of pancreatic proteases on intestinal lactase activity. Gastrocnterology 79:827-832

32. Goldman AS, Smith CW 1973 Host resistance factor in human milk. J Pediat 82:1082-1090

33. Arnold RR. Cole MF. McGhec JR 1977 A bactericidal effect for human lactoferrin. Science 197:263-265

34. Rosner W, Becrs PC, Awan T, Khan MS 1976 Identificationof corticosteroidbinding globulin in human milk: measured with a filter disk assay. $\mathrm{J}$ Clin Endocrinol Metab 42:1064-1073

35. Klagsbrun M 1980 Bovine colostrum support the serum-free proliferation of epithelial cells but not of fibroblasts in long-term culture. J Cell Biol 84:808814

36. Koldovsky O 1980 Hormones in milk. Life Science 26:1833-1836

37. Yeh KY 1984 Corticosterone concentrations in the serum and milk of lactating rats: parallel changes after induced stress. Endocrinology 115:1364-1370 